Article

\title{
Effects of Intermittent Mild Cold Stimulation on mRNA Expression of Immunoglobulins, Cytokines, and Toll-Like Receptors in the Small Intestine of Broilers
}

\author{
Shuang Li ${ }^{1,+}$, Jianhong $\mathrm{Li}^{1,+}+\mathbb{D}$, Yanhong Liu ${ }^{1}$, Chun Li ${ }^{1}$, Runxiang Zhang ${ }^{2, *} \mathbb{D}$ and Jun Bao ${ }^{2, *(\mathbb{D})}$ \\ 1 College of Life Science, Northeast Agricultural University, Harbin 150030, China; \\ 15804639630@163.com (S.L.); jhli@neau.edu.cn (J.L.); lyh_tre@126.com (Y.L.); lichun0917123@163.com (C.L.) \\ 2 Key Laboratory of Chicken Genetics and Breeding, Ministry of Agriculture and Rural Affairs, College of \\ Animal Science and Technology, Northeast Agricultural University, Harbin 150030, China \\ * Correspondence: zhangrunxiang@neau.edu.cn (R.Z.); jbao@neau.edu.cn (J.B.) \\ + These authors equally contributed to the work.
}

Received: 11 August 2020; Accepted: 21 August 2020; Published: 24 August 2020

check for updates

Simple Summary: Cold stress has been associated with adverse effects on health and welfare of broilers. Whilst several studies have shown that long-term sustained and mild cold stimulation can improve immune function, little is known of the effects of intermittent cold stimulation on immune modulation in broilers. In this study, broilers were submitted to cold stimulation of $3{ }^{\circ} \mathrm{C}$ below than the usual rearing temperature during 3 and $6 \mathrm{~h}$ every two days during 43 days to explore its effect on the intestinal immunity. The findings confirm that appropriate mild cold stimulation has an overall positive influence on the intestinal immunity of broilers. The mild cold stimulation tested in this study is cost-effective and likely enhances overall health of broilers.

\begin{abstract}
Appropriate cold stimulation can improve immune function and stress tolerance in broilers. In order to investigate the effect of intermittent mild cold stimulation on the intestinal immunity of broilers, 240 healthy one-day-old Ross 308 chickens were randomly divided into three groups: the control group $(\mathrm{CC})$ housed in climatic chambers under usual rearing ambient temperature with a gradual $3.5^{\circ} \mathrm{C}$ decrease per week; group II (C3) and group III (C6) to which cold stimulation at $3{ }^{\circ} \mathrm{C}$ below the temperature used in CC was applied every two days for 3 and $6 \mathrm{~h}$, respectively, from day 15 to 35 , and at the same temperature used in CC from day 35 to 43 . The mRNA expression levels of immunoglobulins (IgA and $I g G$ ), cytokines (IL2, IL6, IL8, IL17, and IFN $\gamma$ ), and Toll-like receptors (TLR2, TLR4, TLR5, TLR7, and TLR21) were investigated in duodenum, jejunum, and ileum tissue samples on days 22, 29, 35, and 43. From day 15 to 35, mRNA expression of IL2 and IFN $\gamma$ was increased in the intestine of broilers. After one week of cold stimulation on day 43, mRNA levels of immunoglobulins, cytokines, and Toll-like receptors (TLRs) stabilized. Collectively, the findings indicate that cold stimulation at $3{ }^{\circ} \mathrm{C}$ below the usual rearing temperature had a positive impact on intestinal immunity of broilers.
\end{abstract}

Keywords: broilers; cold stimulation; immunoglobulins; cytokines; toll-like receptors; intestinal immunity

\section{Introduction}

Cold stress impairs the performance of broilers by threatening health and welfare [1]. When the usual temperature is low as to induce cold stress in chickens, the immune system can become 
unbalanced [2]. Previous studies have found that appropriate cold stimulation can improve immune function and the ability to withstand cold stress and disease [1,3-5]. It has also been described that early cold conditioning improved late life thermotolerance in broilers challenged at $15^{\circ} \mathrm{C}$ [6]. The intestine is an important responsive organ to cold stimulation due to its unique anatomical characteristics [7]. In fact, chronic cold stress has been shown to induce intestinal inflammation in rats and oxidative stress in quails $[8,9]$, while acute cold stress induces intestinal injury, thus affecting intestinal immune function in broilers [10].

Immunoglobulins play an important role in maintaining intestinal immune function [11]. Certain antibodies produced in the intestinal mucosa can help increase host immune responses to resist endogenous and exogenous infections [12]. In particular, secretory IgA produced in the lamina propria is a vital protective molecule for the intestinal epithelium [13]. Moreover, proper cold stimulation has been shown to increase the expression of intestinal $\operatorname{Ig} A$ and $\operatorname{Ig} G$ to resist adverse effects [14].

Cytokines have an essential function in immunomodulation, participating in pro- and anti-inflammatory processes [15]. Dugué and Leppänen [16] suggested that cytokines can weaken or enhance the effect of adverse or advantageous environments on the human body, and that repeated cold stimulation increases tolerance to disease. Zhao et al. [10] showed that both acute and chronic cold stresses can increase the expression levels of interleukin-2 (IL2) and interleukin-17 (IL17) in the small intestine of chickens, causing tissue damage. Rhind et al. [17] found that long-term cold stimulation increased the levels of interleukin-6 (IL6) in the human serum, which limited the severity of inflammatory response. Previous research done by our group demonstrated that cold stress inhibited Thelper 1 (Th1) cells response in broilers by reducing interferon gamma (IFN $\gamma$ ) and IL2 levels, and long-term sustained stimulus at $3{ }^{\circ} \mathrm{C}$ below the usual temperature did not induce morphological injury, oxidative stress, or inflammation response in the ileum [18].

Intestinal immune function greatly influences organism overall health. Host immune response is elicited against invading microbial pathogens, and Toll-like receptors (TLRs) are constituents of a skillful system that recognize components of pathogenic microorganisms and regulate innate immunity [19]. TLR2 and TLR4 are involved in the intestinal immune response by identifying bacterial components [20]. Furthermore, TLRs signal activation of the NF- $\kappa B$ pathway and induce expression of IL6 and interleukin-8 (IL8) to elicit innate and adaptive immune responses [21]. Paul et al. [22] demonstrated that mRNA expression levels of TLR2, TLR4 and TLR7, as well as the activity of dendritic cells and macrophages, were reduced in the blood of Black Bengal goats submitted to long-term severe cold stress compared to goats housed in usual temperature in winter.

In previous studies, we have found that long-term sustained cold stimulation of $3{ }^{\circ} \mathrm{C}$ below the usual temperature improved immune function, enhanced adaptability to the environment, and conferred protection against injury of late acute cold stress in broilers [14,23]. However, little is known of the effect of a more energy-efficient strategy, i.e., the intermittent mild cold stimulation, on improving immunity in broilers. Therefore, the aim of this study was to evaluate the mRNA expression of immunoglobulins, cytokines and TLRs in the small intestine of broilers submitted to mild cold exposure to $3^{\circ} \mathrm{C}$ below the usual rearing temperature for 3 and $6 \mathrm{~h}$ every two days.

\section{Materials and Methods}

\subsection{Animals and Experimental Design}

All experiments and procedures conducted in the present study have been previously approved by the Institutional Animal Care and Use Committee of the Northeast Agricultural University in Harbin, China (IACUCNEAU20150616). A total of 240 one-day-old Ross 308 male broilers were randomly divided into control group (CC), group II (C3), and group III (C6), each comprising 16 birds in 5 replicates. Broilers were battery caged in three climatic chambers for 43 days and given free access to water, a commercial starter diet $(12.10 \mathrm{MJ} / \mathrm{Kg}$ metabolizable energy [ME], $21 \%$ crude protein [CP]) for the first three weeks, and a commercial growing-finishing $\operatorname{diet}(12.60 \mathrm{MJ} / \mathrm{Kg} \mathrm{ME}, 19 \% \mathrm{CP})$ until 
the conclusion of experiments. Lighting regime was $24 \mathrm{~h}$ of light: $0 \mathrm{~h}$ of dark (24L:0D) for the first 3 days and $23 \mathrm{~h}$ of light: $1 \mathrm{~h}$ of dark (23L:1D) from day 4 onwards. Relative humidity in the chambers was $60-70 \%$ from day 1 to 14 and $40-50 \%$ from day 15 to 43 . Temperature scheme adopted in the experiments is shown in Figure 1. Birds in CC were held under a usual temperature scheme from day 1 to 43 . Cold stimulation conditions consisted of $3{ }^{\circ} \mathrm{C}$ below the temperature used in $\mathrm{CC}$. Commencing at 09:30 am on day 15, birds in C3 and C6 were exposed every two days to cold stimulation for 3 and $6 \mathrm{~h}$, respectively, and standard CC temperature was subsequently restored in both groups. Cold stimulation ceased on day 35 at $17^{\circ} \mathrm{C}$ and all three groups were managed at $20^{\circ} \mathrm{C}$ from days 35 to 43 . One bird from each replicate group was randomly selected and euthanized at 08:00 am on days 15, $22,29,36$, and 43. Sections of the birds' duodenum, jejunum, and ileum were excised, washed with $0.9 \% \mathrm{NaCl}$, immediately frozen in liquid nitrogen, and stored at $-80{ }^{\circ} \mathrm{C}$ for subsequent RNA isolation.

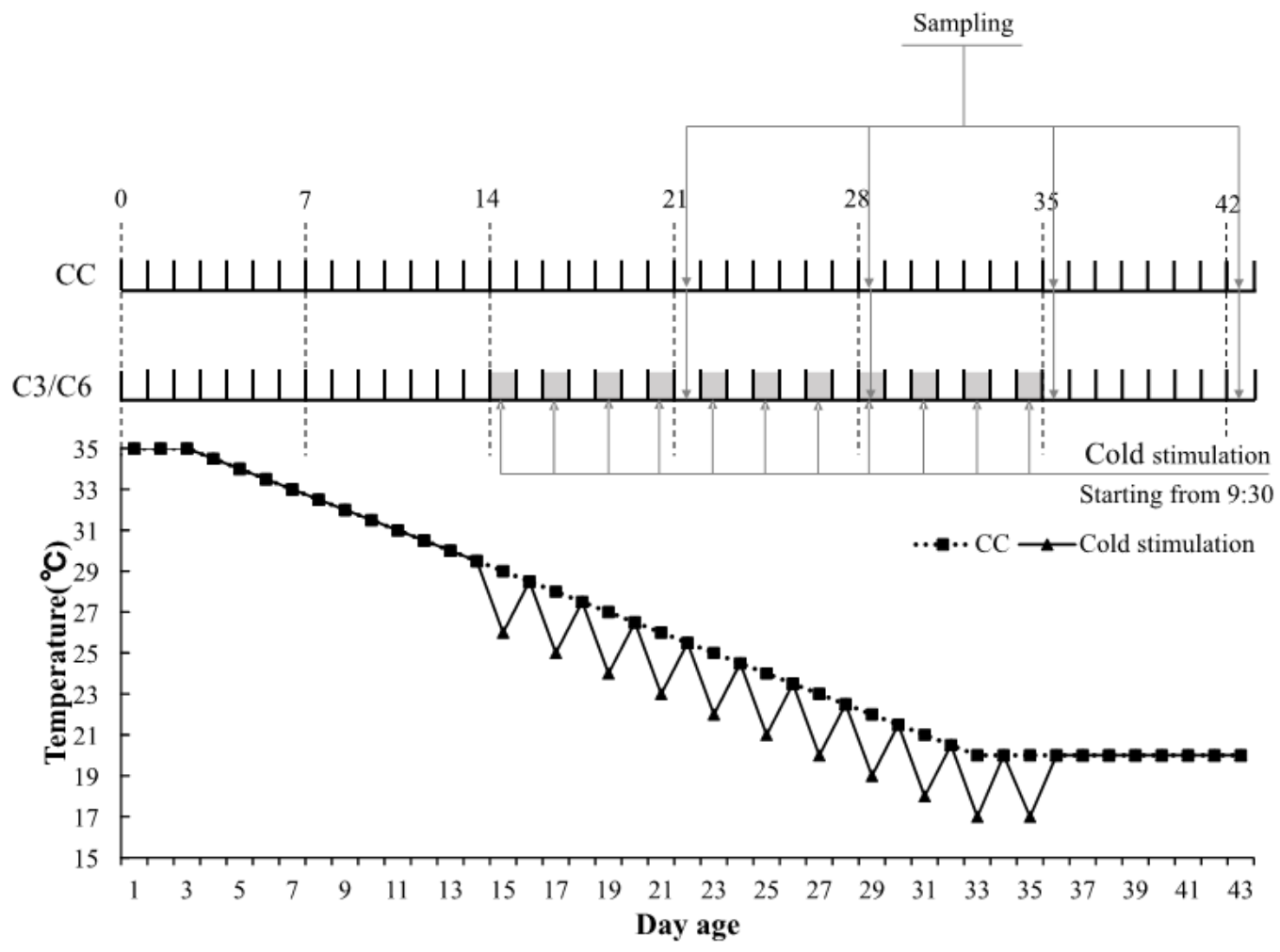

Figure 1. The temperature for experiment scheme.

\subsection{Total RNA Extraction and Reverse Transcription}

Duodenum, jejunum, and ileum tissue samples were ground to powder with a grinding rod using liquid nitrogen. Total cellular RNA was isolated from intestinal tissues using the RNAiso Plus kit (Takara, Japan) according to manufacturer's instructions. Dried RNA pellets were re-suspended in $30 \mu \mathrm{L}$ of DEPC-treated water. Total RNA concentration and purity were determined spectrophotometrically at 260/280 nm and RNA integrity was assessed by horizontal electrophoresis on a 1.5\% agarose gel. Complementary DNA (cDNA) was synthesized using ReverTra Ace ${ }^{\mathrm{TM}}$ qPCR RT Master Mix with gDNA Remover (Toyobo, Osaka, Japan) following manufacturer's instructions and stored at $-80^{\circ} \mathrm{C}$.

\subsection{Quantitative Real-Time PCR ( $q R T-P C R)$}

Genetic sequences available on GenBank for $\beta$-actin, IgA, IgG, IL2, IL6, IL8, IL17, IFN $\gamma$, TLR2, TLR4, TLR5, TLR7 and TLR21 of chicken were used as templates for primer design and subsequent synthesis by Sangon Biotech Co. Ltd. (Shanghai, China). Primer sequences are shown in Table 1. qRT-PCR reactions were performed in a LightCycler ${ }^{\circledR} 96$ (Roche, Switzerland) according to manufacturer's 
instructions. SYBR ${ }^{\circledR}$ Green I dye was incorporated in qRT-PCR reactions using THUNDERBIRD ${ }^{\circledR}$ SYBR $^{\circledR}$ qPCR Mix kit (Toyobo). The $10 \mu \mathrm{L}$-final volume reaction mixture included: $1 \mu \mathrm{L}$ of diluted cDNA, $0.3 \mu \mathrm{L}$ of forward primer $(10 \mathrm{mM}), 0.3 \mu \mathrm{L}$ of reverse primer $(10 \mathrm{mM}), 5 \mu \mathrm{L}$ of SYBR Green I Master, and $3.4 \mathrm{~mL}$ of PCR grade water. qPCR conditions were as follows: initial heating at $95^{\circ} \mathrm{C}$ for $1 \mathrm{~min}$, followed by 40 cycles at $95^{\circ} \mathrm{C}$ for $15 \mathrm{~s}$ and at $60^{\circ} \mathrm{C}$ for $1 \mathrm{~min}$. The melting curve showed a single peak for each PCR product. The house-keeping gene $\beta$-actin was used as an internal reference to determine gene expression. The relative abundance of mRNAs was calculated by the $2^{-\Delta \Delta \mathrm{Ct}}$ method according to Schmittgen and Livak [24].

Table 1. Primer sequences used in the real-time quantitative reverse transcription PCR.

\begin{tabular}{|c|c|c|}
\hline Gene & Reference Sequence & Primer Sequences $\left(5^{\prime}-3^{\prime}\right)$ \\
\hline \multirow[t]{2}{*}{$\beta$-actin } & NM_205518.1 & F: CACCACAGCCGAGAGAGAAAT \\
\hline & & R: TGACCATCAGGGAGTTCATAGC \\
\hline \multirow[t]{2}{*}{$\operatorname{Ig} A$} & NM_205287.1 & F: TGCTAGTGGTTGTGGTGCTTGTG \\
\hline & & R: CGGAGGCGGAGGAGACGATG \\
\hline \multirow[t]{2}{*}{$\operatorname{Ig} G$} & XM_025146241.1 & F: CGATTCCAGCCTCAGCGTCAC \\
\hline & & R: TAGGTGCCGTTGAAGTGTTCTTGG \\
\hline \multirow[t]{2}{*}{$I F N \gamma$} & NM_205149.1 & F: GAACTGGACAGGGAGAAATGAGA \\
\hline & & R: ACGCCATCAGGAAGGTTGTT \\
\hline \multirow[t]{2}{*}{ IL2 } & NM_204153.1 & F: CTGTATTTCGGTAGCAATG \\
\hline & & R: ACTCCTGGGTCTCAGTTG \\
\hline \multirow[t]{2}{*}{ IL6 } & NM_204628.1 & F: AAATCCСТCСТCGCCAATCT \\
\hline & & R: CCCTCACGGTCTTCTCCATAAA \\
\hline \multirow[t]{2}{*}{ IL8 } & NM_205018.1 & F: GGCTTGCTAGGGGAAATGA \\
\hline & & R: AGCTGACTCTGACTAGGAAACTGT \\
\hline \multirow[t]{2}{*}{ IL17 } & NM_204460.1 & F: GCCATTCCAGGTGCGTGAACTC \\
\hline & & R: CGGCGGAGGACGAGGATCTC \\
\hline \multirow[t]{2}{*}{ TLR2 } & XM_001232192294a & F: GATTGTGGACAACATCATTGACTC \\
\hline & & R: AGAGCTGCTTTCAAGTTTTCCC \\
\hline \multirow[t]{2}{*}{ TLR4 } & NM_001030693.1190a & F: AGTCTGAAATTGCTGAGCTCAAAT \\
\hline & & R: GCGACGTTAAGCCATGGAAG \\
\hline \multirow[t]{2}{*}{ TLR5 } & NM_001024586124a & F: CCTTGTGCTTTGAGGAACGAGA \\
\hline & & R: CACCCATCTTTGAGAAACTGCC \\
\hline \multirow[t]{2}{*}{ TLR7 } & NM_001011688219b & F: TTCTGGCCACAGATGTGACC \\
\hline & & R: CCTTCAACTTGGCAGTGCAG \\
\hline \multirow[t]{2}{*}{ TLR21 } & NM_001030558112a & F: TGCCCСTCCCACTGCTGTCCACT \\
\hline & & R: AAAGGTGCCTTGACATCCT \\
\hline
\end{tabular}

\subsection{Statistical Analysis}

Statistical analysis was performed using SPSS21 for Windows (SPSS Inc., Chicago, IL, USA). Two-way ANOVA and Duncan's multiple comparison were used to analyze mRNA levels in small intestine tissue samples in response to cold stimulation and days. Intergroup and intra-group differences at given time points were analyzed by one-way ANOVA with Duncan's multiple comparison. Results are expressed as mean \pm standard error (SE) and probability value of less than 0.05 was significant $(p<0.05)$.

\section{Results}

\subsection{Changes in mRNA Expression Levels of Immunoglobulins}

The effect of cold stimulation experiments on mRNA expression levels of $\operatorname{IgA}$ and $\operatorname{Ig} G$ in the duodenum, jejunum, and ileum of broilers are presented in Figure 2. mRNA levels of $I g A$ and $I g G$ in duodenum and jejunum of broilers were significantly affected by the treatments, age, and the interaction $(p<0.05)$. In the ileum, mRNA levels of $\operatorname{Ig} A$ and $\operatorname{Ig} G$ did not show significant differences $(p>0.05)$ except for the treatment-age interaction $(p<0.05)$. 

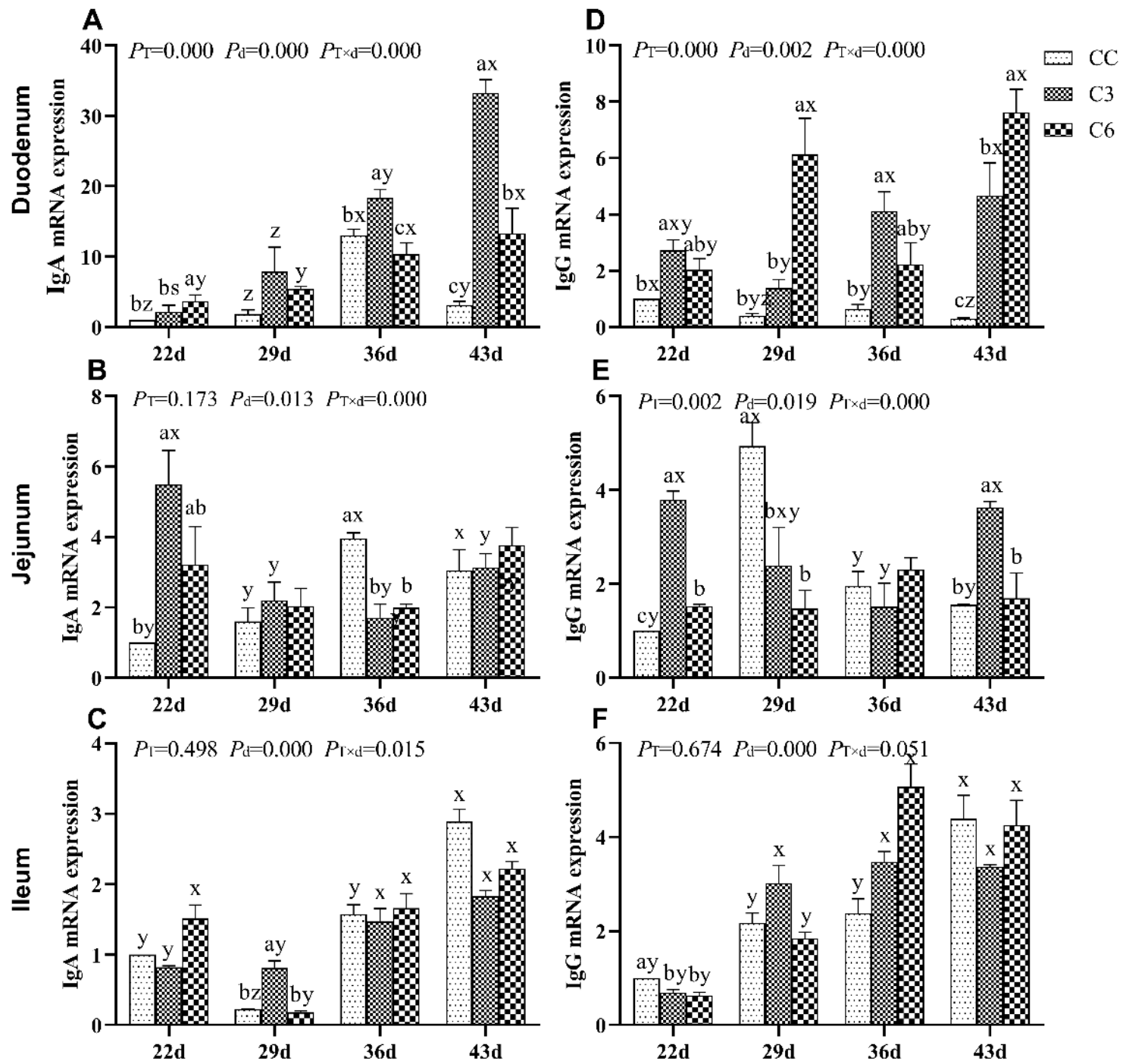

Figure 2. mRNA expression levels of immunoglobulins $\operatorname{Ig} A$ and $\operatorname{Ig} G$ in the duodenum (A,D), jejunum $(\mathbf{B}, \mathbf{E})$, and ileum $(\mathbf{C}, \mathbf{F})$ of broilers. Different letters indicate significant differences $(p<0.05)$ between treatment groups $(a, b, c)$ and days of age $(x, y, z, s)$.

According to Figure 2A, a significant increase in duodenal $\operatorname{Ig} A$ mRNA expression comparing to CC $(p<0.05)$ was found in C3 on days 36 and 43, as well as in C6 on days 22 and 43 . A significant increment in IgA mRNA levels was observed on day 43 in C3 and on day 36 in C6 $(p<0.05)$. Overall, cold stimulation applied to C3 significantly caused an increase in IgA mRNA levels over time $(p<0.05)$ but did not cause the same effect on C6 $(p>0.05)$. According to Figure 2D, considering duodenal IgG mRNA levels, it was found to be significantly enriched in $C 3$ on days 22,36 , and 43 , and in $C 6$ on days 29 and 43 compared to CC $(p<0.05)$. Collectively, duodenal $\operatorname{IgA}$ and $\operatorname{Ig} G$ mRNA levels $(p<0.05)$ were shown to be significantly increased in broilers of $\mathrm{C} 3$ and $\mathrm{C} 6$ groups a week after cold stimulation was removed (i.e., on day 43).

In jejunum tissue, comparing with the $\mathrm{CC}$ group, cold stimulation significantly increased $\operatorname{Ig} A$ mRNA level on day 22 in C 3 and C6 ( $p<0.05$, Figure 2B) with a subsequent decrease on day 36 . No significant difference was found in IgA mRNA levels on days 29 and 43 among all three groups $(p>0.05)$. Interestingly, IgG mRNA levels (Figure 2E) were found to be significantly higher in C3 and $\mathrm{C} 6$ than in CC on day $22(p<0.05)$, but significantly lower in both groups compared to CC on 
day $29(p<0.05)$. Furthermore, $\operatorname{Ig} G$ mRNA expression in C3 on day 43 was significantly higher compared to CC and C6 $(p<0.05)$, but levels found in the latter groups did not differ $(p>0.05)$.

In ileum, the effect of cold stimulation only determined a significant difference in $\operatorname{Ig} A$ mRNA levels of broilers in C3 on day $29(p<0.05$, Figure 2C), but not in C6 $(p>0.05)$ or CC. On the contrast, IgG mRNA levels were found to be decreased in C3 and C6 on day $22(p<0.05$, Figure 2E), but no difference was found on other time points compared to CC $(p>0.05)$.

According to Figure 2F, a significant decrease in ileum $\operatorname{IgG}$ mRNA expression was found in $\mathrm{C} 3$ and $\mathrm{C} 6$ on day 22 compared to $\mathrm{CC}$ group.

As age of broilers progressed, the levels of $I g A$ and $I g G$ mRNA in both $C 3$ and $C 6$ showed a general increasing tendency compared to CC group.

\subsection{Changes in mRNA Expression Levels of Cytokines in Duodenum}

The results of mRNA expression of cytokines in duodenum of broilers are presented in Figure 3. IL2 mRNA levels were significantly affected by the cold stimulation treatment, age, and treatment-age interaction $(p<0.05$, Figure 3A). Compared to CC group, IL2 mRNA levels in C3 were significantly higher on days 22, 36, and $43(p<0.05)$ and in C6 on days 36 and $43(p<0.05)$. As aging progressed, IL2 mRNA expression levels in C 3 and C6 showed a significant fluctuation.

IL6 mRNA level (Figure 3B) was not affected by the cold stimulation treatment $\left(\mathrm{P}_{\mathrm{T}}=0.880\right.$ ) but by the age and treatment-age interaction $(p<0.05)$. Compared to CC, IL6 mRNA levels in C 3 and C6 were lower on day 29 and expressively higher on day $43(p<0.05)$. No difference was found among the three groups on other time points $(p>0.05)$.

When exposed to cold stimulation, IL8 mRNA levels in the duodenum of broilers increased affected by the treatment, age, and treatment-age interaction $(p<0.05$, Figure 3C). The IL8 mRNA level in C3 group was significantly higher CC on days 22,36 , and $43(p<0.05)$. Moreover, IL8 mRNA level was higher in $\mathrm{C} 6$ on day 29 and $36(p<0.05)$. With the progression of days, all three groups showed increased IL8 mRNA levels on days 36 and 43 than on days 22 and $29(p<0.05)$.

Interestingly, cold stimulation treatment did not induce alterations in duodenal IL17 $\left(\mathrm{P}_{\mathrm{T}}=0.486\right.$, Figure 3D) but they were affected by the age and treatment-age interaction $(p<0.05)$. Compared to CC group, the IL17 mRNA was significantly lower in C6 on day 22 and 43 . The IL17 mRNA level in C6 was significantly higher on day 29 compared to CC group and in the case of C3 group the IL17 mRNA was significantly lower on day 43 and higher on 29 day compared to CC group. No consistent trend was verified for mRNA levels of IL17 over time, although significant differences were found in some time points.

IFN $\gamma$ mRNA level was not affected by the cold stimulation treatment $\left(\mathrm{P}_{\mathrm{T}}=0.085\right.$, Figure 3E) but IFN $\gamma$ mRNA level was by the age and treatment-age interaction $(p<0.05)$. IFN $\gamma$ mRNA level was significantly higher in C6 compared to CC on days $36(p<0.05)$, but significantly lower on day 22 $(p<0.05)$. As days progressed, IFN $\gamma$ mRNA levels in all groups fluctuated.

\subsection{Changes in mRNA Expression Levels of Cytokines in Jejunum}

Changes in mRNA levels of cytokines in the jejunum of broilers are presented in Figure 4. mRNA levels of IL2, IL6, IL8, IL17, and IFN $\gamma$ were significantly affected by the cold stimulation treatment, days of age and treatment-age interaction $(p<0.05)$. Overall, mRNA expression of IL2, IL6, IL8, IL17 was significantly higher on days 22 and 29 in groups exposed to cold stimulation.

Compared to CC, IL2 mRNA expression in C3 was significantly higher on days 22 and $29(p<0.05$, Figure $4 \mathrm{~A})$ and in C6 on day $36(p<0.05)$. As days progressed, IL2 mRNA levels in C3 decreased between days 29 to 36, and in C6 increased on day 29 and then it also remains at the same level on days 36 and 43 .

IL6 mRNA level was found to be significantly increased in C3 on days 22 and $43(p<0.05)$, and showed no consistent trend across days of age in all groups (Figure 4B). 
IL8 mRNA expression in C3 showed a significant increase compared to CC on days 22 and 29 $(p<0.05$, Figure 4C), but no difference in IL8 mRNA levels was found between C6 and CC on day 29, 36, and 43 ( $p>0.05)$. No trend was found in IL8 mRNA expression among all groups with age progression.

IL17 mRNA levels in C3 and C6 showed a significant increase compared to CC only on day 22 $(p<0.05$, Figure 4D). A significant higher IL17 mRNA level was in all groups on day 22 than on days 29,36 , and 43 , respectively $(p<0.05)$.

IFN $\gamma$ mRNA levels were significantly higher in C6 compared to C3 and CC on days 36 and 43, but lower than C3 and CC groups on day 22 ( $p<0.05$, Figure 4E), tending to increase in C6 as days progressed. No specific trend in IFN $\gamma$ mRNA levels was found in C3 and CC over time.

\section{Duodenum}
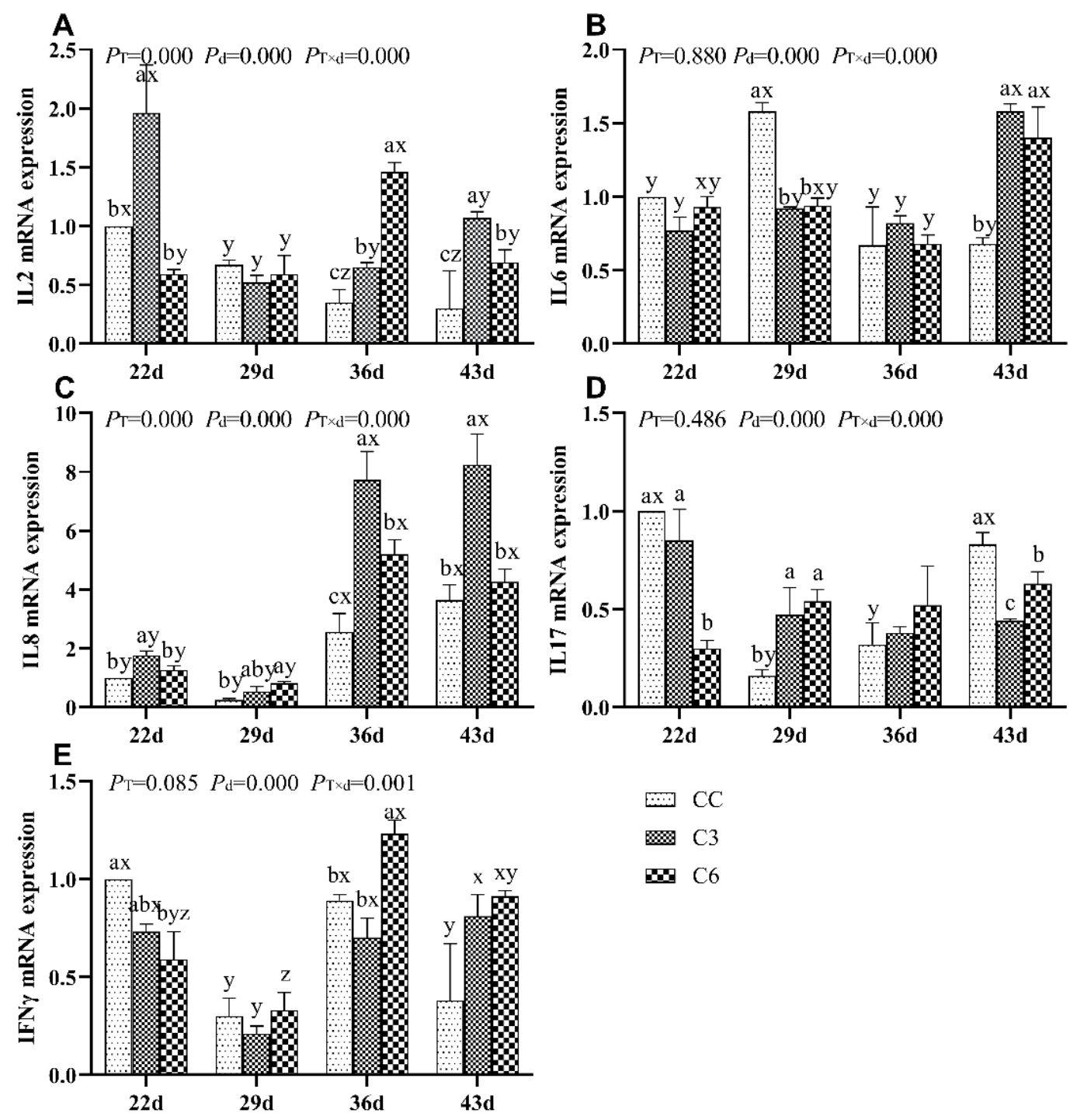

Figure 3. mRNA levels of cytokines IL2 (A), IL6 (B), IL8 (C), IL17 (D), and IFN $\gamma(\mathbf{E})$ in the duodenum of broilers. Different letters indicate significant differences $(p<0.05)$ between treatment groups $(a, b, c)$ and days of age $(x, y, z)$. 


\section{Jejunum}
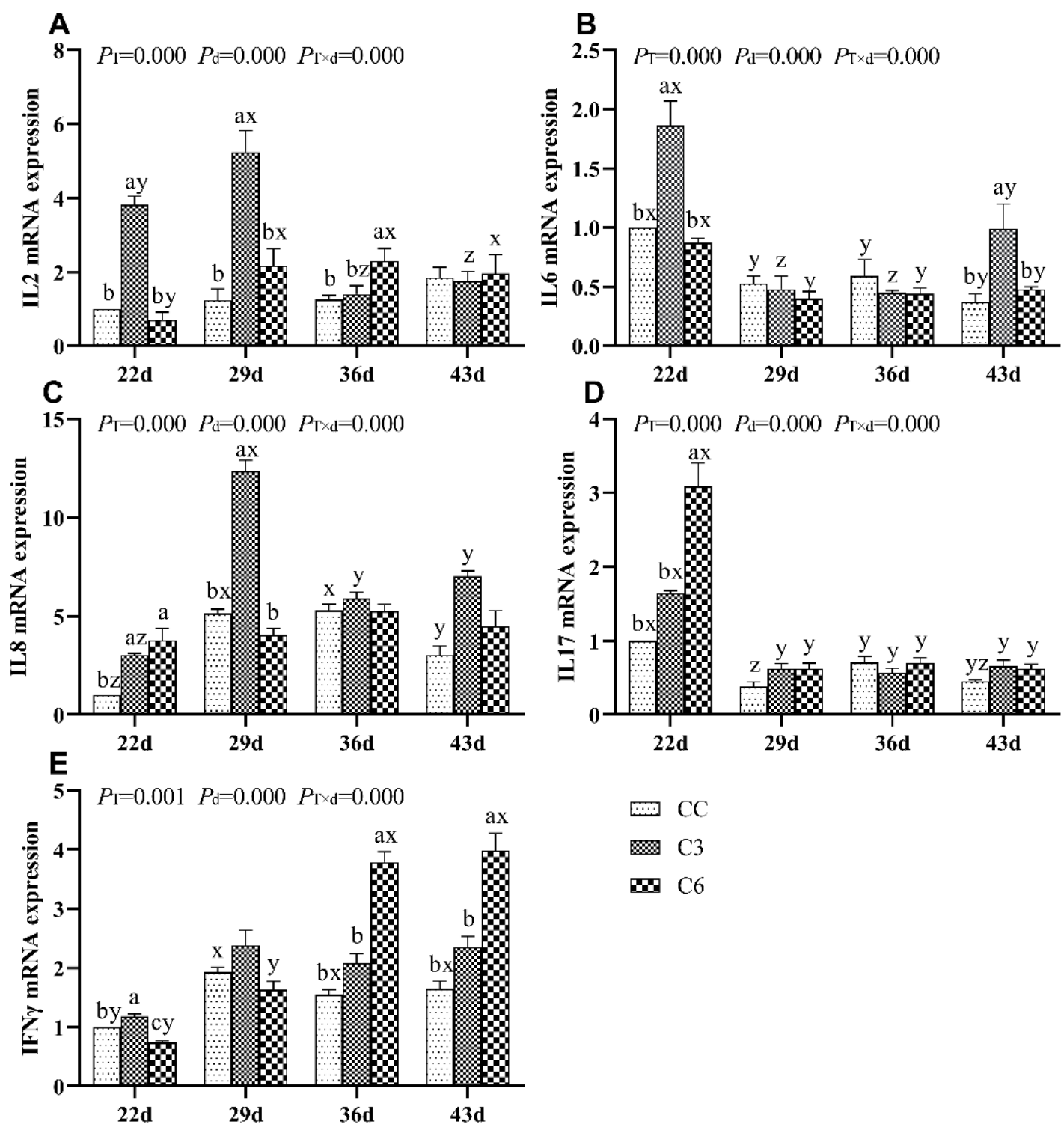

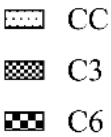

Figure 4. mRNA levels of cytokines IL2 (A), IL6 (B), IL8 (C), IL17 (D), and IFN $\gamma(\mathbf{E})$ in the jejunum of broilers. Different letters indicate significant differences $(p<0.05)$ between treatment groups $(a, b, c)$ and days of age $(x, y, z)$.

\subsection{Changes in mRNA Expression Levels of Cytokines in Ileum}

The results of mRNA levels of cytokines in ileum are shown in Figure 5. mRNA levels of IL2, IL6, and IL8 were significantly affected by the cold stimulation treatment, as seen throughout age and treatment-age interaction $(p<0.05)$. IL17 mRNA level was also affected by treatment-age interaction $(p<0.05)$. 


\section{Ileum}
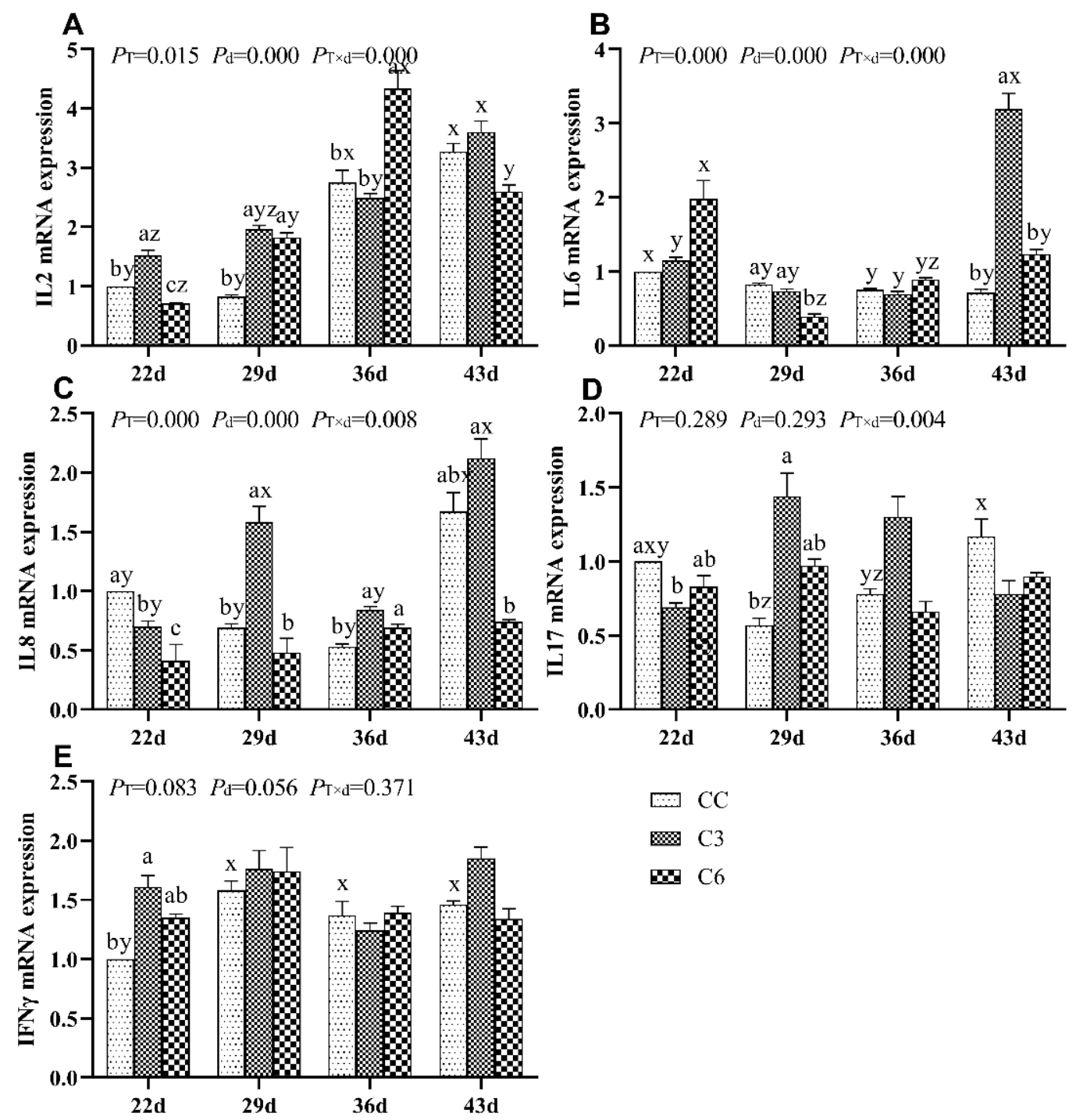

Figure 5. mRNA levels of cytokines IL2 (A), IL6 (B), IL8 (C), IL17 (D), and IFN $\gamma$ (E) in the ileum of broilers. Different letters indicate significant differences $(p<0.05)$ between treatment groups $(a, b, c, d)$ and days of age $(x, y, z)$.

IL2 mRNA levels in C3 showed an increasing tendency as days progressed and were significantly higher on days 22 and 29 compared to CC ( $p<0.05$, Figure 5A). In C6, IL2 mRNA expression was lower on day 22 and higher on days 29 and 36 compared to CC group $(p<0.05)$. On day 43 , there were no differences in IL2 mRNA levels among C3, C6, and CC $(p>0.05)$.

IL6 mRNA level was significantly increased in C3 on day 43 and decreased in C6 on day 29 compared to CC ( $p<0.05$, Figure 5B), and no significant trend for IL6 mRNA levels was found in C3 and $\mathrm{C} 6$ over time.

IL8 mRNA levels in C3 and C6 were significantly lower on day 22 than those in CC $(p<0.05$, Figure 5C). IL8 mRNA level was higher in C3 on days 29 and 36 but lower in C6 on day 43 compared to CC $(p<0.05)$. No varying trend in IL8 mRNA expression was found over time in all groups.

IL17 mRNA level (Figure 5D) was found to be lower on day 22 and higher on day 29 in C3 than $\mathrm{CC}$, and IFN $\gamma$ mRNA expression was significantly enriched in C3 (Figure 5E) than in CC on day 22 $(p<0.05)$. No difference was found in the mRNA levels of IL17 and IFN $\gamma(p>0.05)$ among all three groups on other time points. 


\subsection{Changes in mRNA Expression Levels of TLRs in Duodenum}

The results of mRNA expression levels of TLRs in duodenum are shown in Figure 6. mRNA levels of TLR2, TLR4, TLR7, and TLR21 were significantly affected by cold stimulation treatment and age $(p<0.05)$, but TLR5 mRNA levels were only significantly affected by cold stimulation treatment $(p<0.05)$. mRNA levels of TLR4, TLR5, and TLR21 were also significantly affected by the treatment-age interaction $(p<0.05)$.

\section{Duodenum}
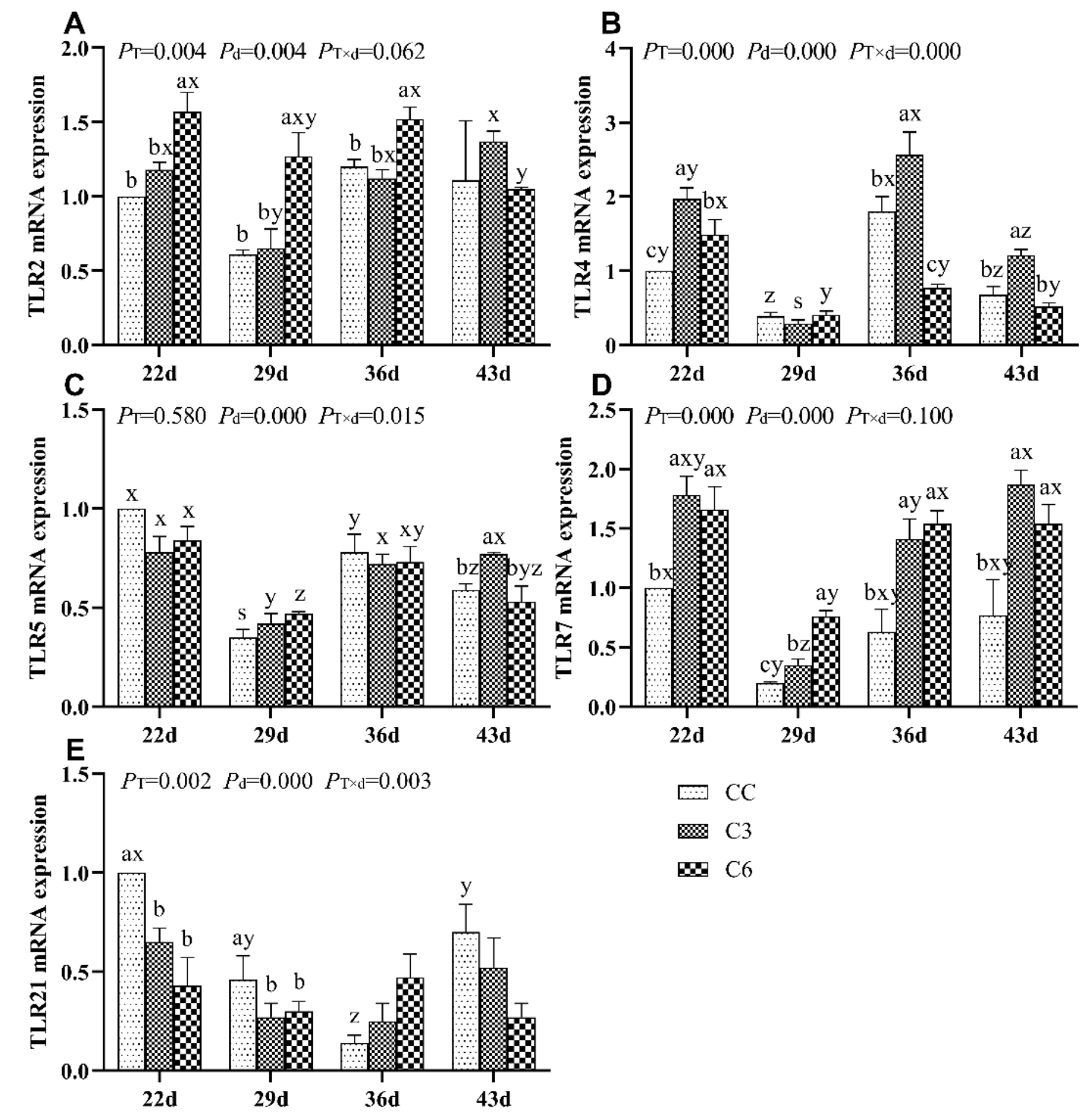

Figure 6. mRNA levels of Toll-like receptors TLR2 (A), TLR4 (B), TLR5 (C), TLR7 (D), and TLR21 (E) in the duodenum of broilers. Different letters indicate significant differences $(p<0.05)$ between treatment groups $(a, b, c, d)$ and days of age $(x, y, z, s)$.

TLR2 mRNA levels in C6 on days 22, 29, and 36 were significantly higher than in C3 and CC $(p<0.05$, Figure 6A). TLR2 mRNA expression in C3 decreased from days 22 to 29 and then increased on day 36 , but no trend for TLR2 mRNA expression was found in $\mathrm{C} 6$ and CC with age progression. 
TLR4 mRNA level was found to be significantly higher in C3 compared to C6 and CC on days 22, 36 , and 43 ( $p<0.05$, Figure 6B), and no difference was found between C6 and CC on day $43(p>0.05)$. TLR4 mRNA level showed no trend across days of age in all groups.

TLR5 mRNA level was significantly enriched in C3 on day $43(p<0.05$, Figure 6 C) compared to C6 and CC $(p>0.05)$. No noticeable trend of TLR $5 \mathrm{mRNA}$ levels was found over time in the tested groups.

TLR7 mRNA levels were found to be affected by the cold stimulation treatment, and significantly higher TLR7 mRNA expression was found in C3 and C6 on days 22, 29, 36, and 43 ( $p<0.05$, Figure 6D). TLR7 mRNA levels in all groups tended to decrease between days 22 to 29 and then increase on day 43.

Comparing with CC, TLR21 mRNA expressions in C3 and C6 were significantly lower on days 22 and 29 ( $p<0.05$, Figure 6E). When birds were submitted to cold exposure, TLR21 mRNA level in CC significantly decreased as age progressed $(p<0.05)$, and then significant increased on day $43(p<0.05)$, but the expression of TLR21 in C3 and C6 did not show the trend with age $(p>0.05)$.

\subsection{Changes in mRNA Expression Levels of TLRs in Jejunum}

The fluctuations in mRNA levels of TLRs in jejunum of broilers are shown in Figure 7. mRNA levels of TLR2, TLR4, TLR5, TLR7, and TLR21 were significantly affected by the cold stimulation treatment, age, and the interaction between treatment and age $(p<0.05)$.

TLR2 mRNA levels in C3 and C6 on days 22, 29, and 43 were significantly higher than in CC $(p<0.05$, Figure 7A), while expression in C3 on day 36 was lower than that in C6 and CC $(p<0.05)$. No trend was found for TLR2 mRNA expression over age among tested groups.

TLR4 mRNA expression was lower on days 22,36 , and 43 in C 3 compared to CC ( $p<0.05$, Figure 7B), while in C6 group was higher on day 43 and lower on $22 \mathrm{~d}$ than CC group $(p<0.05)$. All groups showed a higher TLR4 mRNA level on 36d than other detected time points, respectively $(p<0.05)$.

TLR5 mRNA level was found to be significantly higher in C6 compared to C3 and CC on day 22 $(p<0.05$, Figure 7C). TLR5 mRNA level was significantly lower in C3 compared to C6 and CC on day 36. There was no regular trend found for TLR5 mRNA level over days.

After one week of ceasing exposure to cold (day 43), TLR7 mRNA levels in C3 and C6 were higher than in CC $(p<0.05$, Figure 7D). Interestingly, a significant increasing trend in TLR7 mRNA expression was observed in C6 $(p<0.05)$.

When cold stimulation exposure completed one week (day 22), TLR21 mRNA level (Figure 7E) was found to be significantly increased in C6 $(p<0.05)$ compared to C3 and CC $(p<0.05)$. All groups showed increased TLR21 mRNA levels on day 22, which progressively decreased in subsequent time points $(p<0.05)$.

\subsection{Changes in mRNA Expression Levels of TLRs in Ileum}

Levels of mRNA expression of TLRs in ileum are presented in Figure 8. TLR2 mRNA expression (Figure $8 \mathrm{~A}$ ) was not affected by cold stimulation $\left(\mathrm{P}_{\mathrm{T}}=0.443\right)$ but by age and treatment-age interaction $(p<0.05)$. TLR2 mRNA levels in C6 showed significant lower compared to CC on days 22 and 43 $(p<0.05)$, and higher on day $36(p<0.05)$, whereas no difference in TLR2 mRNA levels was found between C3 and CC on days 29, 36, and 43 ( $p>0.05)$. Moreover, TLR2 mRNA levels in C3 were significantly lower compared to CC on days $22(p<0.05)$. TLR2 mRNA levels in C6 and CC tended to be decreased on days 22 and 29 , and increased as days progressed.

TLR4 mRNA expression was affected by treatment, age, and treatment-age interaction $(p<0.05$, Figure 8B). Significant increase in TLR4 mRNA expression was found in C3 compared to CC on day 43 $(p<0.05)$, and the expression in $\mathrm{C} 3$ and CC tended to increase over time.

TLR5 mRNA level was not affected by treatment $\left(\mathrm{P}_{\mathrm{T}}=0.060\right)$ but by age and treatment-age interaction ( $p<0.05$, Figure 8C). TLR5 mRNA level in C6 was higher than in C3 on day 36 and in CC on day 22 ( $p<0.05)$. As days progressed, TLR5 mRNA levels in all groups fluctuated.

Application of cold stimulation treatment and age were found to not affect TLR7 mRNA levels $(p>0.05$, Figure 8D) but treatment-age interaction showed a significant effect $(p<0.05)$. TLR7 mRNA 
levels in C3 and CC were lower than in C6 on day 36. With age, TLR7 mRNA levels in CC tended to increase.

TLR21 level was not affected by age ( $p<0.05$, Figure $8 \mathrm{E})$ but by treatment and treatment-age interaction ( $p>0.05)$. TLR21 mRNA levels in C3 and CC were higher than in C6 on day 29. TLR21 mRNA level in $\mathrm{C} 6$ and $\mathrm{CC}$ also fluctuated over time.

\section{Jejunum}
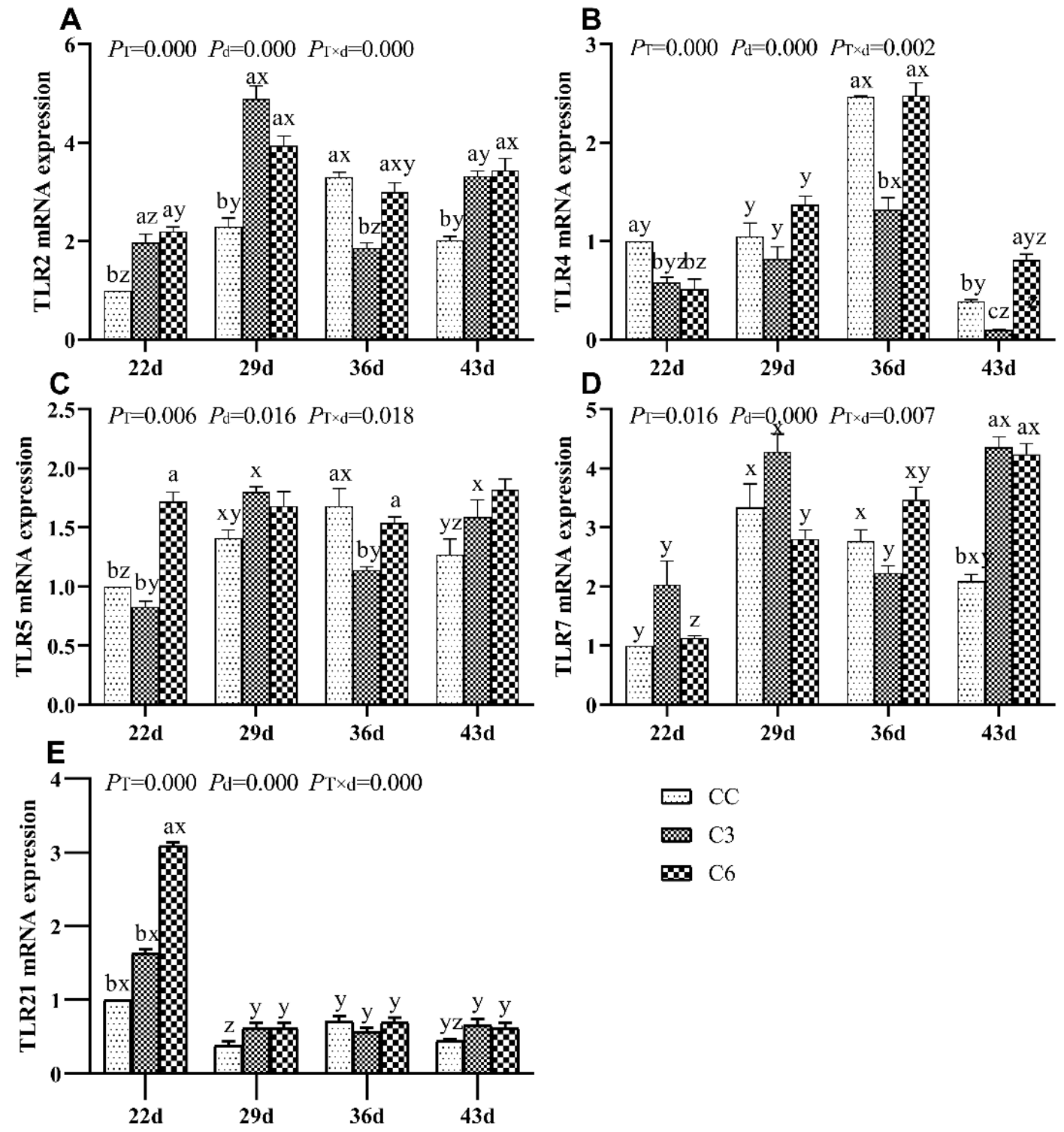

Figure 7. mRNA levels of Toll-like receptors TLR2 (A), TLR4 (B), TLR5 (C), TLR7 (D), and TLR21 (E) in the jejunum of broilers. Different letters indicate significant differences $(p<0.05)$ between treatment groups $(a, b, c)$ and days of age $(x, y, z)$. 
Ileum
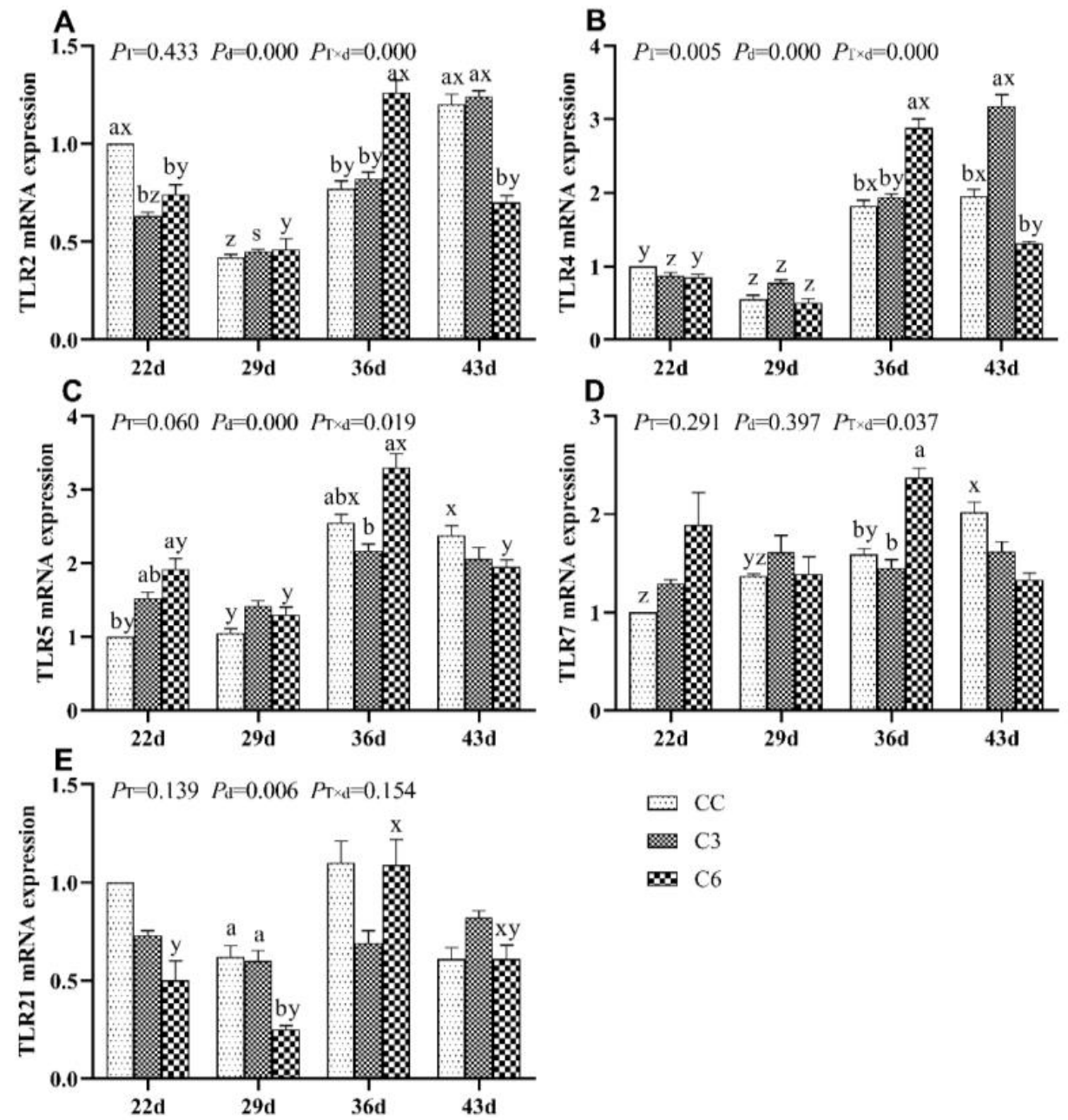

$\square \mathrm{CC}$

짐 $\mathrm{C} 3$

B. 66

Figure 8. mRNA levels of Toll-like receptors TLR2 (A), TLR4 (B), TLR5 (C), TLR7 (D), and TLR21 (E) in the ileum of broilers. Different letters indicate significant differences $(p<0.05)$ between treatment groups $(a, b)$ and days of age $(x, y, z, s)$.

\section{Discussion}

Cold stress induces a pronounced suppression of humoral and cellular immune responses [25,26]. Proper cold stimulation can improve immune function and enhance resistance to diseases [3,27]. It has been demonstrated that cold stimulation enhances or suppresses cell-mediated immune response, depending on the duration and degree of exposure to the usual temperature [28-30]. In previous studies, we showed that sustained long-term cold stimulation conditions $\left(3{ }^{\circ} \mathrm{C}\right.$ below the usual rearing temperature) applied from eight days of age did not induce damage in broilers $[23,31]$. In the present study, mRNA expression levels of immune-related genes of broilers was investigated after an intermittent cold stimulation at $3{ }^{\circ} \mathrm{C}$ below the usual temperature still can modulate the intestinal immunity of broilers.

Immunoglobulins are a major component of the immune system, playing an important role in the intestinal immune function [32]. IgA, the most abundant immunoglobulin in the intestinal tract, is a key barrier of mucosal immunity [33]. Carr et al. [34] indicated that a proper cold stimulus can regulate autoimmune function by mediating immunoglobulin production, who found that the expression of intestinal $\operatorname{IgG}$ and $\operatorname{IgA}$ was increased when mice were placed in a $-20^{\circ} \mathrm{C}$ freezer 20 min per day. Zhao et al. [10] showed that the expression levels of $\operatorname{Ig} A$ and $\operatorname{Ig} G$ had an increased tendency in acute and 
chronic cold stress. Su et al. $[14,18]$ suggested that long-term and sustained cold stimulation increase the gene levels of immunoglobulin in ileum of broilers. Similar to previous studies, our results show a gradual increasing tendency in mRNA levels of $\operatorname{Ig} A$ and $I g G$ in the small intestine of broilers submitted to intermittent mild cold stimulation. $I g A$ and $I g G$ mRNA levels in C3 and C6 were higher than in $\mathrm{CC}$, showing a significant increase in $\mathrm{C} 3$ as from day 22 of age. Collectively, our results indicate that exposure to a lower usual temperature might contribute to improving the intestinal immune function of broilers via stimulation of local immunoglobulin production. Our results were also consistent with previous reports by Hangalapura [28,30], in which has been demonstrated that broilers that had undergone a proper cold stimulation at an early age showed an enhanced immune function in late life.

Cytokines also play a key role in intestinal immunity under cold stimulation [10]. Th1 cells regulate and produce cytokines (most importantly IL2 and IFN $\gamma$ ) to participate in cellular immunity, while T-helper 2 (Th2) cells mainly trigger IL6 to mediate humoral immunity [35,36]. IL8 activated neutrophils to clear pathogenic infections [37]. It has been reported that chronic cold stimulation upregulates mRNA expression levels of IL2 and IL6, without significantly affecting IFN $\gamma$ mRNA levels in chicken [38]. In human, cold stimulation was shown to increase serum IL6 levels, especially at the initial phase of stimulation [39,40]. Hangalapura et al. [28] reported that cold stimulation can enhance Th1 related cellular immunity of chickens, consequently, increase the IL2 and IFN $\gamma$ mRNA levels. Additionally, the acute cold stimulation increased IL8 levels in human lungs, and firstly increased then decreased the mRNA expression of proinflammatory cytokine IL17 [41]. In this the present study, mRNA expression levels of intestinal IL2 and IFN $\gamma$ in C3 were higher than those in CC at the start of cold stimulation, which indicated that the broilers aimed to have a resistant capacity to the cold ambient by enhancing the Th1-mediated cellular immunity. At 43 days of age, mRNA expression of ileum IL2 and IFN $\gamma$ tended to stabilize. mRNA expression of IL6 was slightly higher in duodenum C3 and C6 than in CC during cold stimulation treatment but did not show significant differences in levels detected in the jejunum and ileum after cold stimulation ceased. In addition, IL6 mRNA levels in C3 group were significantly enriched compared to those in C6 and CC at 43 days of age, which might be an indication that broilers can suitably be managed at $3{ }^{\circ} \mathrm{C}$ below usual temperature.

TLRs are central components of the innate immune system and serve as the first line of host defense against invading microbial pathogens [42]. TLR signaling pathways are activated in response to temperature stress and lead to the release of endogenous molecules that serve as TLR ligands $[43,44]$. Heat stress can affect TLRs expression and modulate responsiveness of the innate and the adaptive immune system to fight pathogenic microorganisms [22]. TLR2 is a low-affinity lipopolysaccharide (LPS) receptor, while TLR4 transmits LPS signals [45]. Chronic cold stimulation triggers the overexpression of TLR4 and indirectly stimulates hypothermia in humans [46]. TLR5 can recognize bacterial flagellin [47]. Intracellular receptors TLR7 and TLR9 cooperate to distinguish host and exogenous nucleic acid-specific [48]. TLR21 has a seemingly similar function in mammals [49]. When rats were infected necrotic enteritis and simultaneously exposed to acute cold stress at $4{ }^{\circ} \mathrm{C}$ for $10 \mathrm{~min}, \mathrm{mRNA}$ expression levels of TLR2 and TLR4 in groups submitted to cold stress were significantly higher than those in control group, and the expressions in jejunum were lower than those in the ileum [50]. Basu et al. [51] found that with the reduction of cold stimulation temperature in 20, 15 and $10{ }^{\circ} \mathrm{C}$, mRNA levels of TLR2 were strongly increased then decreased equally to control group at $25^{\circ} \mathrm{C}$ in the liver and kidney of catfish. mRNA level of TLR4 increased with the decreased temperature of cold stimulating, and the mRNA level of TLR5 was lower than that in control group [51]. Our results showed that TLR2 mRNA levels in the duodenum and ileum of broilers in C3 were lower than in CC, while TLR4 and TLR2 mRNA levels were similar in the jejunum and ileum between C6 and CC. In contrast, no difference was observed in TLR5 mRNA expression between CC group and cold stimulation group in small intestine. We speculated that the cold stimulus at $3{ }^{\circ} \mathrm{C}$ below the usual temperature for 3 and $6 \mathrm{~h}$ would slightly stimulate the body, which would in turn positively affect the immune defense function of the small intestine against the invasion of pathogenic microorganisms. There was no significant difference between control and cold stimulated groups regarding the mRNA 
expression of TLR2, TLR4, and TLR5. Interestingly, TLR7 mRNA expression in C3 and C6 was significantly higher than in CC, while TLR21 mRNA expression in C3 and C6 was significantly lower than in CC in the duodenum. Thus, long intermittent cold exposure ought to modulate the existing microbiome in the gut of broilers, for recognition of pathogen-associated molecular patterns to occur by TLR7 and TLR21 and enable the activation of immune cells in the small intestine.

\section{Conclusions}

The findings presented herein indicated that mild cold stimulation conditions at $3{ }^{\circ} \mathrm{C}$ below the usual temperature for 3 and $6 \mathrm{~h}$ every two days may have a positive impact on the intestinal immunity of broilers, as demonstrated by an upregulation of mRNA expression of intestinal immunoglobulins, cytokines, and TLRs.

Author Contributions: Conceptualization, S.L., J.L. and R.Z.; Data curation, S.L. and Y.L.; Formal analysis, J.L.; Investigation, J.L.; Methodology, S.L., Y.L. and C.L.; Resources, J.B.; Software, S.L.; Supervision, J.B.; Validation, S.L. and J.L.; Visualization, R.Z.; Writing—original draft, S.L.; Writing—review \& editing, R.Z. All authors have read and agreed to the published version of the manuscript.

Funding: This research was funded by the Natural Science Foundation of China (Grant No. 31772647).

Acknowledgments: The authors thank the members of animal behavior and welfare laboratory at College of Animal Science and Technology in Northeast Agricultural University.

Conflicts of Interest: The authors declare no conflict of interest.

\section{References}

1. Hangalapura, B.N. Cold Stress and Immunity: Do Chickens Adapt to Cold by Trading-Off Immunity for Thermoregulation? Wageningen University and Research Centre: Wageningen, NLD, The Netherlands, 2006.

2. Jia, Z.; Chen, A.; Wang, C.; He, M.; Xu, J.; Fu, H.; Zhang, X.; Lv, W.; Guo, Z. Amelioration effects of Kaempferol on immune response following chronic intermittent cold-stress. Res. Vet. Sci. 2019, 125, 390-396. [CrossRef]

3. Liu, Y.; Xue, G.; Li, S.; Fu, Y.; Yin, J.; Zhang, R.; Li, J. Effect of Intermittent and Mild Cold Stimulation on the Immune Function of Bursa in Broilers. Animals 2020, 10, 1275. [CrossRef] [PubMed]

4. Rintamäki, H. Predisposing factors and prevention of frostbite. Int. J. Circumpolar Health 2000, 59, 114-121. [PubMed]

5. Yang, Z.; Liu, C.; Zheng, W.; Teng, X.; Li, S. The functions of antioxidants and heat shock proteins are altered in the immune organs of selenium-deficient broiler chickens. Biol. Trace Elem. Res. 2016, 169, 341-351. [CrossRef] [PubMed]

6. Shinder, D.; Luger, D.; Rusal, M.; Rzepakovsky, V.; Bresler, V.; Yahav, S. Early age cold conditioning in broiler chickens (Gallus domesticus): Thermotolerance and growth responses. J. Therm. Biol. 2002, 27, 517-523. [CrossRef]

7. Furness, J.B.; Rivera, L.R.; Cho, H.J.; Bravo, D.M.; Callaghan, B. The gut as a sensory organ. Nat. Rev. Gastroenterol. Hepatol. 2013, 10, 729-740. [CrossRef]

8. Fu, J.; Liu, C.P.; Zhang, Z.W.; Xing, M.W.; Xu, S.W. Influence of inflammatory pathway markers on oxidative stress induced by cold stress in intestine of quails. Res. Vet. Sci. 2013, 95, 495-501. [CrossRef]

9. Kaushik, S.; Kaur, J. Effect of chronic cold stress on intestinal epithelial cell proliferation and inflammation in rats. Stress Int. J. Biol. Stress 2005, 8, 191-197. [CrossRef]

10. Zhao, F.Q.; Zhang, Z.W.; Yao, H.D.; Wang, L.L.; Liu, T.; Yu, X.Y.; Li, S.; Xu, S.W. Effects of cold stress on mRNA expression of immunoglobulin and cytokine in the small intestine of broilers. Res. Vet. Sci. 2013, 95, 146-155. [CrossRef]

11. Shira, E.B.; Friedman, A. Innate immune functions of avian intestinal epithelial cells: Response to bacterial stimuli and localization of responding cells in the developing avian digestive tract. PLOS ONE 2018, 13, e0200393.

12. Perozo, F.; Finol, G.; Mavarez, Y. Levels of immunoglobulin-a in trachea, gut and bile samples of chickens vaccinated against newcastle disease. Rev. Científica 2007, 17, 226-230. 
13. Zhang, X.; Zhang, X.; Yang, Q. Effect of compound mucosal immune adjuvant on mucosal and systemic immune responses in chicken orally vaccinated with attenuated Newcastle-disease vaccine. Vaccine 2007, 25, 3254-3262. [CrossRef] [PubMed]

14. Su, Y.; Li, S.; Xin, H.; Li, J.; Li, X.; Zhang, R.; Li, J.; Bao, J. Proper cold stimulation starting at an earlier age can enhance immunity and improve adaptability to cold stress in broilers. Poult. Sci. 2019, 99, 129-141. [CrossRef] [PubMed]

15. Kawaguchi, M.; Adachi, M.; Oda, N.; Kokubu, F.; Huang, S.-K. IL-17 cytokine family. J. Allergy Clin. Immunol. 2004, 114, 1265-1273. [CrossRef]

16. Dugué, B.; Leppanen, E. Adaptation related to cytokines in man: Effects of regular swimming in ice-cold water. Clin. Physiol. 2000, 20, 114-121. [CrossRef]

17. Rhind, S.G.; Castellani, J.W.; Brenner, I.K.; Shephard, R.J.; Zamecnik, J.; Montain, S.J.; Young, A.J.; Shek, P.N. Intracellular monocyte and serum cytokine expression is modulated by exhausting exercise and cold exposure. Am. J. Physiol. Regul. Integr. Comp. Physiol. 2001, 281, R66-R75. [CrossRef]

18. Su, Y.; Zhang, X.; Xin, H.; Li, S.; Li, J.; Zhang, R.; Li, X.; Li, J.; Bao, J. Effects of prior cold stimulation on inflammatory and immune regulation in ileum of cold-stressed broilers. Poult. Sci. 2018, 97, 4228-4237. [CrossRef]

19. Takeda, K.; Akira, S. Toll-like receptors in innate immunity. Int. Immunol. 2005, 17, 1-14. [CrossRef]

20. Cario, E. Bacterial interactions with cells of the intestinal mucosa: Toll-like receptors and NOD2. Gut 2005, 54, 1182-1193. [CrossRef]

21. Cosseau, C.; Devine, D.A.; Dullaghan, E.; Gardy, J.L.; Chikatamarla, A.; Gellatly, S.; Lorraine, L.Y.; Pistolic, J.; Falsafi, R.; Tagg, J. The commensal Streptococcus salivarius K12 downregulates the innate immune responses of human epithelial cells and promotes host-microbe homeostasis. Infect. Immun. 2008, 76, 4163-4175. [CrossRef]

22. Paul, A.; Dangi, S.S.; Gupta, M.; Singh, J.; Thakur, N.; Naskar, S.; Nanda, P.K.; Mohanty, N.; Das, A.K.; Bandopadhayay, S. Expression of TLR genes in Black Bengal goat (Capra hircus) during different seasons. Small Rumin. Res. 2015, 124, 17-23. [CrossRef]

23. Wei, H.; Zhang, R.; Su, Y.; Bi, Y.; Li, X.; Zhang, X.; Li, J.; Bao, J. Effects of Acute Cold Stress After Long-Term Cold Stimulation on Antioxidant Status, Heat Shock Proteins, Inflammation and Immune Cytokines in Broiler Heart. Front. Physiol. 2018, 9, 1589. [CrossRef] [PubMed]

24. Schmittgen, T.D.; Livak, K.J. Analyzing real-time PCR data by the comparative CT method. Nat. Protoc. 2008, 3, 1101-1108. [CrossRef] [PubMed]

25. Svensson, E.; Råberg, L.; Koch, C.; Hasselquist, D. Energetic stress, immunosuppression and the costs of an antibody response. Funct. Ecol. 1998, 12, 912-919. [CrossRef]

26. Rybakina, E.G.; Shanin, S.N.; Kozinets, I.A.; Fomicheva, E.E.; Korneva, E.A. Cellular mechanisms of cold stress-related immunosuppression and the action of interleukin 1. Int. J. Tissue React. 1997, 19, 135-140.

27. Banerjee, S.K.; Aviles, H.; Fox, M.T.; Monroy, F.P. Cold Stress-Induced Modulation of Cell Immunity during Acute Toxoplasma gondii Infection in Mice. J. Parasitol. 1999, 85, 442-447. [CrossRef]

28. Hangalapura, B.; Nieuwland, M.; de Vries Reilingh, G.; Heetkamp, M.; van den Brand, H.; Kemp, B.; Parmentier, H. Effects of cold stress on immune responses and body weight of chicken lines divergently selected for antibody responses to sheep red blood cells. Poult. Sci. 2003, 82, 1692-1700. [CrossRef]

29. Hangalapura, B.N.; Nieuwland, M.G.B.; Buyse, J.; Kemp, B.; Parmentier, H.K. Effect of Duration of Cold Stress on Plasma Adrenal and Thyroid Hormone Levels and Immune Responses in Chicken Lines Divergently Selected for Antibody Responses. Poult. Sci. 2006, 83, 1644-1649. [CrossRef]

30. Hangalapura, B.N.; Nieuwland, M.G.B.; de Vries Reilingh, G.; van den Brand, H.; Kemp, B.; Parmentier, H.K. Durations of cold stress modulates overall immunity of chicken lines divergently selected for antibody responses. Poult. Sci. 2004, 83, 765-775. [CrossRef]

31. Su, Y.; Wei, H.; Bi, Y.; Wang, Y.; Zhao, P.; Zhang, R.; Li, X.; Li, J.; Bao, J. Pre-cold acclimation improves the immune function of trachea and resistance to cold stress in broilers. J. Cell. Physiol. 2019, 234, 7198-7212. [CrossRef]

32. Woof, J.M.; Kerr, M.A. The function of immunoglobulin A in immunity. J. Pathol. A J. Pathol. Soc. Great Br. Irel. 2006, 208, 270-282. [CrossRef] [PubMed] 
33. Reyna-Garfias, H.; Miliar, A.; Jarillo-Luna, A.; Rivera-Aguilar, V.; Pacheco-Yepez, J.; Baeza, I.; Campos-Rodríguez, R. Repeated restraint stress increases IgA concentration in rat small intestine. Brain Behav. Immun. 2010, 24, 110-118. [CrossRef] [PubMed]

34. Carr, D.J.J.; Woolley, T.W.; Blalock, J.E. Phentolamine but not propranolol blocks the immunopotentiating effect of cold stress on antigen-specific IgM production in mice orally immunized with sheep red blood cells. Brain Behav. Immun. 1992, 6, 50-63. [CrossRef]

35. Diehl, S.; Rincón, M. The two faces of IL-6 on Th1/Th2 differentiation. Mol. Immunol. 2002, 39, 531-536. [CrossRef]

36. McAdam, A.J.; Pulaski, B.A.; Harkins, S.S.; Hutter, E.K.; Lord, E.M.; Frelinger, J.G. Synergistic effects of co-expression of the Th1 cytokines il-2 and IFN $\gamma$ on generation of murine tumor-reactive cytotoxic cells. Int. J. Cancer 1995, 61, 628-634. [CrossRef]

37. Ito, K.; Hanazawa, T.; Tomita, K.; Barnes, P.J.; Adcock, I.M. Oxidative stress reduces histone deacetylase 2 activity and enhances IL-8 gene expression: Role of tyrosine nitration. Biochem. Biophys. Res. Commun. 2004, 315, 240-245. [CrossRef]

38. Hangalapura, B.N.; Kaiser, M.G.; van der Poel, J.J.; Parmentier, H.K.; Lamont, S.J. Cold stress equally enhances in vivo pro-inflammatory cytokine gene expression in chicken lines divergently selected for antibody responses. Dev. Comp. Immunol. 2006, 30, 503-511. [CrossRef]

39. Brenner, I.; Castellani, J.; Gabaree, C.; Young, A.; Zamecnik, J.; Shephard, R.; Shek, P. Immune changes in humans during cold exposure: Effects of prior heating and exercise. J. Appl. Physiol. 1999, 87, 699-710. [CrossRef]

40. Castellani, J.W.; Brenner, I.K.; Rhind, S.G. Cold exposure: Human immune responses and intracellular cytokine expression. Med. Sci. Sports Exerc. 2002, 34, 2013-2020. [CrossRef]

41. Luo, B.; Shi, H.; Wang, L.; Shi, Y.; Wang, C.; Yang, J.; Wan, Y.; Niu, J. Rat Lung Response to PM2.5 Exposure under Different Cold Stresses. Int. J. Environ. Res. Public Health 2014, 11, 12915-12926. [CrossRef]

42. He, H.; Genovese, K.J.; Swaggerty, C.L.; MacKinnon, K.M.; Kogut, M.H. Co-stimulation with TLR3 and TLR21 ligands synergistically up-regulates Th1-cytokine IFN- $\gamma$ and regulatory cytokine IL-10 expression in chicken monocytes. Dev. Comp. Immunol. 2012, 36, 756-760. [CrossRef] [PubMed]

43. Arslan, F.; de Kleijn, D.P.; Pasterkamp, G. Innate immune signaling in cardiac ischemia. Nat. Rev. Cardiol. 2015, 8, 292-300. [CrossRef] [PubMed]

44. Napper, S.; Dadgar, S.; Arsenault, R.J.; Trost, B.; Scruten, E.; Kusalik, A.; Shand, P. Induction of tissueand stressor-specific kinomic responses in chickens exposed to hot and cold stresses. Poult. Sci. 2015, 94, 1333-1345. [CrossRef] [PubMed]

45. Yang, R.B.; Mark, M.R.; Gray, A.; Huang, A.; Godowski, P.J. Toll-like receptor-2 mediates lipopolysaccharide-induced cellular signalling. Nature 1998, 395, 284-288. [CrossRef] [PubMed]

46. Okla, M.; Wang, W.; Kang, I.; Pashaj, A.; Carr, T.; Chung, S. Activation of Toll-like Receptor 4 (TLR4) Attenuates Adaptive Thermogenesis via Endoplasmic Reticulum Stress. J. Biol. Chem. 2015, 290, 26476-26490. [CrossRef] [PubMed]

47. Gewirtz, A.T.; Navas, T.A.; Lyons, S.; Godowski, P.J.; Madara, J.L. Cutting Edge: Bacterial Flagellin Activates Basolaterally Expressed TLR5 to Induce Epithelial Proinflammatory Gene Expression. J. Immunol. 2001, 167, 1882-1885. [CrossRef]

48. Blasius, A.L.; Beutler, B. Intracellular Toll-like Receptors. Immunity 2010, 32, 305-315. [CrossRef]

49. Keestra, A.M.; de Zoete, M.R.; Bouwman, L.I.; van Putten, J.P.M. Chicken TLR21 Is an Innate CpG DNA Receptor Distinct from Mammalian TLR9. J. Immunol. 2010, 185, 460-467. [CrossRef]

50. Zhou, W.; Li, W.; Zheng, X.-H.; Rong, X.; Huang, L.-G. Glutamine downregulates TLR-2 and TLR-4 expression and protects intestinal tract in preterm neonatal rats with necrotizing enterocolitis. J. Pediatr. Surg. 2014, 49, 1057-1063. [CrossRef]

51. Basu, M.; Paichha, M.; Swain, B.; Lenka, S.S.; Singh, S.; Chakrabarti, R.; Samanta, M. Modulation of TLR2, TLR4, TLR5, NOD1 and NOD2 receptor gene expressions and their downstream signaling molecules following thermal stress in the Indian major carp catla (Catla catla). 3 Biotech 2015, 5, 1021-1030. [CrossRef] 